\title{
Recent Advances in Three-Dimensional Multicellular Spheroid Formation for Biomedical Research
}

\author{
Jae Hong Park iD \\ Department of Otorhinolaryngology-Head and Neck Surgery, Soonchunhyang University College of Medicine, Cheonan, Korea
}

3 차원 생체모사체 제작의 최신지견

박재홍

순천향대학교 의과대학 천안병원 이비인후과학교실

\author{
Received February 28, 2020 \\ Revised April 2, 2020 \\ Accepted April 3, 2020 \\ Address for correspondence \\ Jae Hong Park, MD, PhD \\ Department of Otorhinolaryngology- \\ Head and Neck Surgery, \\ Soonchunhyang University \\ College of Medicine, \\ 31 Suncheonhyang 6-gil, \\ Dongnam-gu, Cheonan 31151, Korea \\ Tel $+82-41-570-2265$ \\ Fax $+82-41-591-3803$ \\ E-mail entparkong@hanmail.net
}

Multicellular spheroids (MCSs) from three dimensional culture, which is a complex architectural structure with dynamic cell to cell and cell to matrix interactions, mimic real tissues regarding structural and functional properties. MCSs have emerged as an effective tool for filling up the gap between the in vitro and in vivo experimental model and can replace the in vivo model. The viability and functional performance can be enhanced when cells are grown as multicellular spheroid (MCS). In this review paper, we discussed the basic mechanism of MCS formation, their biomedical applications, and recent advances in MCS culture and tissue engineering.

Korean J Otorhinolaryngol-Head Neck Surg 2020;63(6):245-51

Key Words Multicellular spheroids · Cell culture techniques · Tissue engineering.

\section{서 론}

Moscona \& Moscona(advances in multicellular spheroids formation-5)에 의해 처음 소개된 3차원 장기유사체는 세포간 그리고 세포와 기질간의 상호작용을 동반한 세포의 집합체로 생체의 구조와 기능을 모사하여 생체 내(in-vivo) 실험과 유사한 환경을 구현함으로써 이미 다양한 기초 생물 학과 임상 적용을 목표로 하는 다양한 연구에 활용되고 있 다. 과거, 오가노이드란 단어는 1차 조직(primary tissue) 또는 그보다 하위 1차 세포(primary cell), 배아 줄기세포(embryonic stem cell) 및 유도만능줄기세포(induced pluripotent stem cell), 세포주(cell line), 그리고 여러 조직 유형들로 구성 된 장기 외식편(explant)과 같은 전체 또는 분절된 기관에서

This is an Open Access article distributed under the terms of the Creative Commons Attribution Non-Commercial License (https://creativecommons.org/licenses/by-nc/4.0) which permits unrestricted non-commercial use, distribution, and reproduction in any medium, provided the original work is properly cited.
비롯된 모든 3차원 기관형 배양체(organotypic culture)를 포함하여 일컫는 용어였다. 그러나, 최근 많은 문헌들에서는 장기모사체를 줄기세포로부터 분화하여 체외(in-vitro)에서 다세포 인체유사조직으로 분화시켜 생산하는 오가노이드 (Organoid)와 이미 분화된 인체장기의 세포를 분리하여 체 외(in-vitro)에서 3차원 배양에 의해 구모양으로 만들어지는 스페로이드(spheroid)로 크게 구분하여 부르기도 한다.

오가노이드 또는 스페로이드와 같은 3차원 배양기법이 2차 원 단층배양에 비해 생리학적으로 실제 생체 내 환경과 매우 유사하고, 생존능력(viability)과 기능성이 향상되며 생체 내 모델보다 주변미세환경 구성요소(niche component), 신호 전 달 경로 및 유전체 조작을 통한 기능향상이 훨씬 더 간편하기 때문에 전통적인 2차원 단층배양과 생체 내 동물/인간 모델 사이의 중요한 역할을 할 수 있다. ${ }^{2)}$

본 문헌에서는 최근 다양한 기초연구 분야 뿐만 아니라 임 상적인 적용까지 시도되고 있는 최신 3차원 세포배양기법들 
을 분화된 1차 세포를 이용한 스페로이드 제작법에 중점을 두어 설명하고자 한다.

\section{본 론}

\section{스페로이드 형성과정}

스페로이드를 형성하기 위한 세포간 유착 및 분화는 1) 인 테그린(integrin)과 세포외기질(extracellular matrix)의 결합 에 의한 불완전한 세포응집(cell aggregation), 2) 캐드헤린 (cadherin)의 발현과 축적, 3) 캐드헤린 간(cadherin to cadherin)의 동종친화성 상호작용(homophilic interaction)에 의한 구체(spheroid)조직 형성의 3단계로 구분된다(Fig. 1). ${ }^{3)}$

스페로이드는 생성초기에는 혈관성이 없는 조직(avascular tissue)으로 150 200 $\mu \mathrm{m}$ 이내의 제한된 범위 내에서 확산 (diffusion)에 의해 필요한 물질과 산소를 외부로부터 공급받 게 되며 내부의 대사노폐물을 배출한다.

따라서, 직경 $500 \mu \mathrm{m}$ 를 초과하는 스페로이드는 흔히 내부 의 괴사조직(necrotic core)과 외부의 생존조직(viable rim)이 띠 모양으로 층구조를 형성하고 있으며 생존조직은 다시 내 부의 휴지기세포 구역(quiescent viable cell zone)과 증식세 포구역(proliferating zone)으로 나뉜다(Fig. 2).
이렇게 생성된 스페로이드는 2차원 단층배양된 조직과 비 교하여 더 생존력이 높고 다양한 유전자가 발현되며 이 유전 자들은 모사하고자 하는 생체 조직에 고유한 유전자 전사인 자를 포함하고 있어 실제 생체 조직과 더 유사한 기능을 갖게 된다고 보고된 바 있다.)

특히, 이러한 고유한 조직 특성을 효과적이고 안정적으로 발현하는 장점은 종양 연구에 있어 매우 가치 있는 점이라 할 수 있겠다.

지금까지 보고된 많은 연구에서 볼 수 있듯이 스페로이드

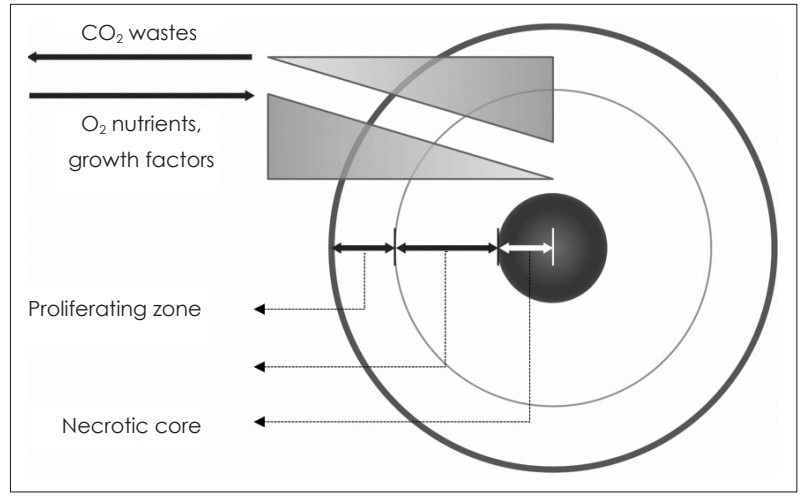

Fig. 2. Micro-geography inside a spheroid. Spheroids show spherical structures comprise proliferating, quiescent and dead cells.

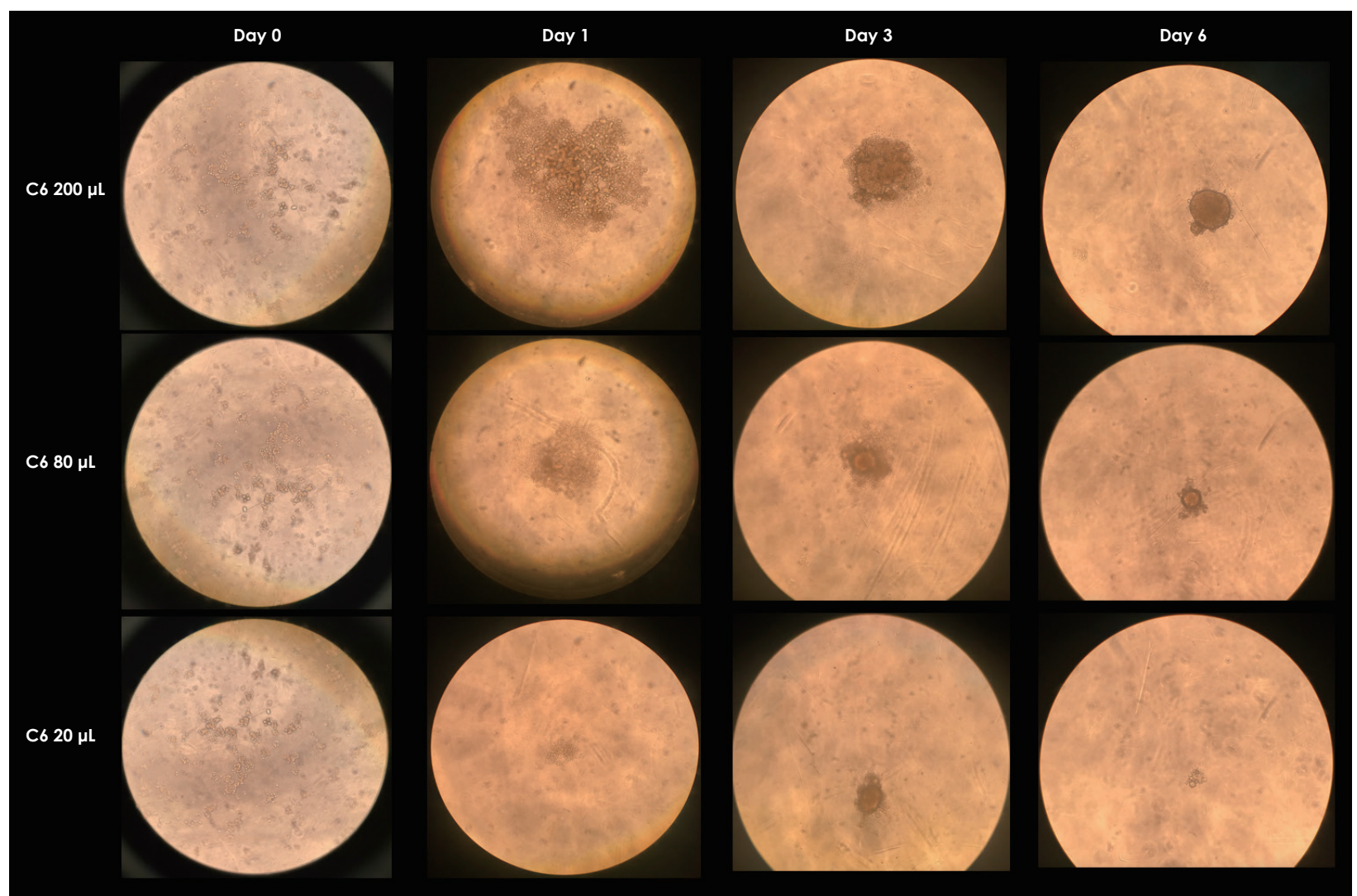

Fig. 1. Inverted bright field microscopic images of spheroids from single cell culture on non-adhesive surface in chronological sequence. 
는 다양한 연구분야에 적용되고 있으며 대표적인 예로는 종 양의 치료 효용성 평가, 유전자 기능 분석을 이용한 발암성 기전 연구 및 세포 괴사-형성 과정에 대한 연구, 혈관 조직 생성에 있어 세포 간 상호작용과 서로 다른 조직으로의 분화 과정에 대한 연구와 장기 프린팅(organ printing)과 같은 장 기 재생의 조직공학적 시도에 적용되고 있다. ${ }^{6-11)}$

\section{스페로이드 제작기법들}

스페로이드를 이용한 연구에 단순하고 재현성이 좋은 스페
로이드 제작 방법은 필수적이라 할 수 있다. 스페로이드 제작 에 있어 가장 기본적인 요소는 세포들이 배양 접시에 유착되 지 않고 배양되는 것이며 다양한 제작법들 중 연구 목적에 맞 는 방법을 선택함에 있어 스페로이드 제작의 효율성, 제작된 스페로이드 크기의 균일성, 제작과정에서 발생 가능한 세포 고유기능의 영향, 제작 편이성과 연구 적합성을 고려하여 선 택하여야 한다. 후술할 각 제작기법들은 Fig. 3과 Table 1에 각각의 원리와 장단점을 정리하였다.
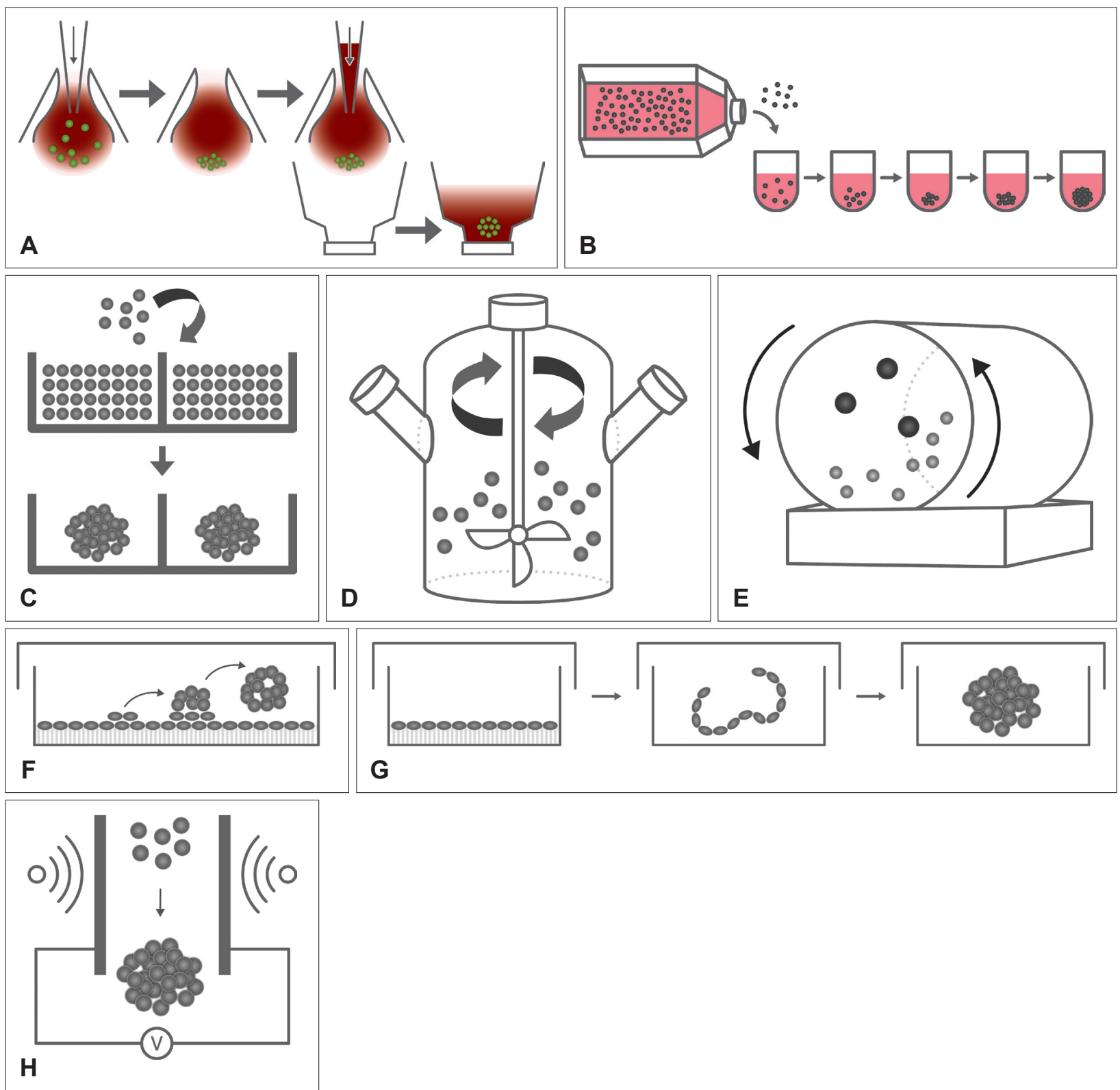

Fig. 3. Methods for spheroid fabrication. Hanging-drop culture (A). Single cell culture on non-adhesive surface (B). Micromolding techniques (C). Spinner flask culture (D). Rotary cell culture systems (E). Hepatocyte self-assembly on Primaria dishes (F). The use of PNIPAAm based cell sheets $(\mathrm{G})$. Electric, magnetic or acoustic force cell aggregation enhancement (H). PNIPAAm: poly(N-isopropylacrylamide). 


\section{현적배양(haning-drop cultures)}

현적배양(haning-drop cultures)은 세포액 방울이 배양 접 시 위에 위치한 배양판에 매달린 채로 방울 내부의 세포들이 중력에 의해 아래에 응집하여 조직을 형성하게 되는 원리이 다(Figs. 3A and 4). 각 세포 방울의 용량은 $15 ~ 30 \mu \mathrm{L}$ 크기 이며 각 세포액 방울 당 대략 300 3000개의 세포를 내부에
포함할 수 있다.,12) 4 7일 후 스페로이드 조직이 완성되면 세 포방울이 아래쪽에 매달린 모래시계 모양의 마이크로채널 (microchannel)의 위쪽 입구에 세포액을 주입하는 방식으로 완성된 스페로이드를 아래로 밀어내 내부에 유착방지처리 된 배양용기에 담아 배양하게 된다. 이 기법은 스페로이드의 크 기, 내부의 세포수와 세포구성을 균일하게 조절하여 제작할

Table 1. Spheroid fabrication methods

\begin{tabular}{|c|c|c|c|}
\hline Method & Advantage & Disadvantage & References \\
\hline \multirow[t]{4}{*}{ Hanging drop } & Simple to perform & Labor intensive & $6,58,62,64,104$ \\
\hline & Well-controlled spheroid size & Massive production difficult & \\
\hline & Fast spheroid formation & & \\
\hline & Co-culture of different cell types & & \\
\hline \multirow[t]{3}{*}{ Non-adhesive surface } & Inexpensive & Variation in size/shape & $56,65,66$ \\
\hline & Simple to perform & & \\
\hline & Easy to scale up & & \\
\hline \multirow[t]{3}{*}{ Micromolding } & Well-controlled spheroid size & Require specialized facilities & \\
\hline & Designed aggregate geometry & & \\
\hline & Co-culture of different cell types & & \\
\hline \multirow[t]{5}{*}{ Spinner flasks } & Simple to perform & Require specialized equipment & $52,53,73$ \\
\hline & Massive production & Variation in size/cell number & \\
\hline & Long-term culture & High shear force & \\
\hline & Dynamic control of culture conditions & & \\
\hline & Co-culture of different cell types & & \\
\hline \multirow[t]{6}{*}{ NASA rotary system } & Simple to perform & Require specialized equipment & 75,76 \\
\hline & Massive production & Variation in size/cell number & \\
\hline & Long-term culture & & \\
\hline & Dynamic control of culture conditions & & \\
\hline & Better cell differentiation & & \\
\hline & Co-culture of different cell types & & \\
\hline \multirow[t]{3}{*}{ PNIPAAm cell sheet } & Prevent anoikis-induced cell death & Labor intensive & 81,82 \\
\hline & Well-mixed co-culture & Massive production difficult & \\
\hline & & Time consuming & \\
\hline \multirow{2}{*}{$\begin{array}{l}\text { External force } \\
\text { enhancement }\end{array}$} & Rapid cell aggregation & Potentially undefined effects to cells & $93-95$ \\
\hline & & $\begin{array}{l}\text { Require specialized equipment and } \\
\text { culture conditions }\end{array}$ & \\
\hline
\end{tabular}

PNIPAAm: poly(N-isopropylacrylamide)
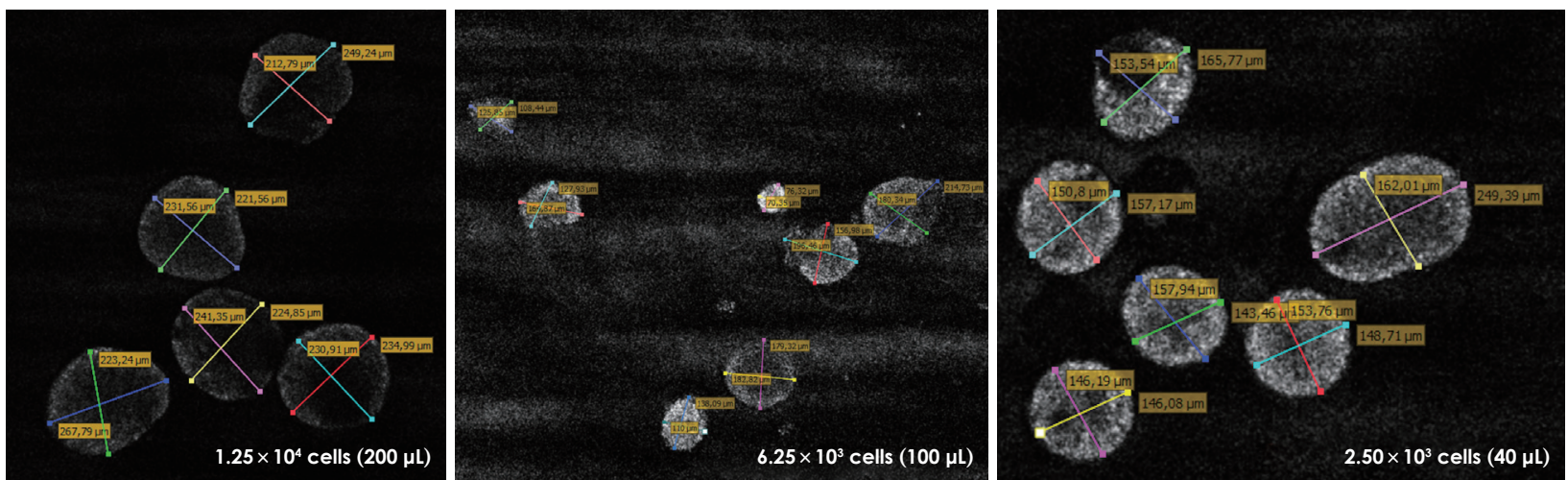

Fig. 4. Confocal laser scanning microscopic images of spheroids from different cell concentration at 7 days after cell seeding into hanging-drop culture system. Note the necrotic central core in each spheroid. 
수 있는 장점이 있어 스페로이드 제작 중 발생할 수 있는 세 포 및 분자단위의 현상에 대한 연구, 종양의 침습에 대한 연 구, 이종의 세포간 상호작용 및 조직의 혈관화 과정에 대한 연구에 적용되고 있다. ${ }^{13-15)}$

\section{표면유착방지처리 마이크로 웰 플레이트(microwell plates with non-adhesive surface)}

가장 단순하면서 용이한 방법으로 세포가 표면에 유착되지 않게 내부처리 된 하단이 둥근 마이크로 웰 플레이트(microwell plate with non-adhesive surface) 내에 세포를 함유 한 배양액을 담아 중력에 의해 세포들이 아래로 모이면서 둥 근 조직을 형성하게 되는 원리로 초심자들도 쉽게 시행할 수 있는 용이한 방법이면서 균일한 크기와 세포조성을 조절할 수 있는 장점이 있다(Fig. $3 \mathrm{~B})$. 다만, 현적배양에 비해 크기의 균일성이 다소 떨어질 수 있으나 다른 방법들에 비해 비교적 균일한 크기의 스페로이드를 만들 수 있고, 방법 또한 현적배 양에 비해 용이하여 가장 흔하게 이용되는 방법이라고 볼 수 있다. 이 방법의 경우 현적배양과 같이 다양한 연구분야에 적 용되고 있으며 스페로이드의를 세포액 내의 세포농도 및 마 이크로 웰의 크기를 조절함으로써 다양한 크기로 제작가능 하다. ${ }^{16,17)}$

미세제작구조틀(microfabricated microstructures)을 이용한 배양

이 방법은 전술한 마이크로 웰 플레이트를 이용한 배양과 그 원리는 같으나 아가로즈(agarose) 또는 폴리에틸렌 글리콜 (Polyethylene glycol)과 같은 불활성물질을 이용하여 세포 액을 담는 마이크로 웰을 제작의도에 맞게 설계하는 마이크 로몰딩(micromolding) 기법을 사용한다(Fig. $3 \mathrm{C}$ ). 스페로이 드의 크기, 세포조성 및 내부구조를 다양한 형태로 미세하게 조절할 수 있는 점이 장점이다. ${ }^{18-23)}$

\section{회전 바이오리액터}

내부에 유착방지처리 된 회전 플라스크(spinner flask)(Fig. 3D)와 롤러 보틀(roller bottle)(Fig. 3E)을 이용하여 대량으 로 스페로이드를 제작할 수 있는 방법으로 정적인 배양법에 비해 동적으로 회전하는 배양용기 안에서 만들어지는 스페 로이드는 상대적으로 그 모양에 있어 균일하며 동시에 대량 의 스페로이드를 제작할 수 있고, 크기 또한 회전 속도와 세포 액의 세포농도를 조절하여 다양하게 제작할 수 있는 장점이 있다. 반면 회전 플라스크와 같이 수평면으로 회전하는 배양 용기의 회전속도가 너무 빠르게 되면 전단력(shear force)이 강해져 세포의 생리학적 반응에 영향을 줄 수 있는 단점이
있다. ${ }^{24,25)}$ 최근 미국의 National Aeronautics and Space $\mathrm{Ad}-$ ministration에서 이를 보완하기 위해 전단력을 낮추고, 대 신 중력을 더해 구르는 운동으로 회전을 대신한 롤러 보틀을 개발하여 회전 플라스크를 대체하고 있다. ${ }^{26,27)}$

\section{표면조절 배양기 또는 스캐폴드(surface modified substrates or scaffolds)}

최근 기능화된 표면재료들을 이용한 스페로이드 제작법들 이 소개되고 있다. 대표적인 예로 표면에 양전하를 띤 Primaria dishes(BD Biosciences, Franklin Lakes, NJ, USA) (Fig. 3F)로 세포를 배양하게 되면 배양 초기에는 세포들이 표면에 단층으로 퍼져서 배양되다가 48시간 후에는 actin filament를 매개로 한 조직 재구성 과정으로 세포들이 구축, 이동과 전이의 과정을 거쳐 2 차원적인 단층구조에서 3 차원 구체모양의 구조로 말려들게 된다. 유사한 재료로 galactosylated poly(vinylidene difluoride) 또는 polyethylene terephthalate film이 있다. ${ }^{28,29)}$

온도차를 이용한 방법 또한 소개된 바 있는데, thermosresponsive poly(N-isopropylacrylamide)로 처리된 표면의 배양용기에 세포를 배양시키면 용기 바닥으로부터 부유하는 단층구조의 세포층이 형성되고 배양온도를 낮추게 되면 세 포층의 가장자리부터 말려드는 수축현상이 발생하여 구체모 양의 조직을 형성하게 되는 원리이다(Fig. $3 \mathrm{G}$ ). 상기 방법들 로 만들어진 스페로이드는 원심분리를 통해 용기로부터 분리 해낼 수 있다. ${ }^{30-32)}$ 기타 polyurethane foam으로 제작한 다공 성 3-D 스캐폴드(porous 3-D scaffold)를 이용하여 세포들의 자가 응집을 물리적으로 지지하는 방법도 있다. ${ }^{33,34)}$

\section{외력(external forces)을 이용한 스페로이드 제작}

저속 원심분리, 유전영동(dielectrophoresis), 자성(magnetic field) 및 초음파를 이용한 트랩(ultrasound standing wave trap)와 같은 다양한 외부의 힘을 이용하여 세포응집력을 향 상시킬 수 있으며 세포 응집이 용이하지 않은 가혹한 조건에 서 스페로이드를 제작해야 하는 경우에 보조적인 방법으로 사용된다(Fig. $3 \mathrm{H}) .{ }^{35-37)}$

\section{스페로이드 칩(spheroid on a chip)}

최근에는 대량의 생체모사체를 이용한 약물스크리닝 실험 을 위해 마이크로웰(microwell) 또는 마이크로채널을 칩 (chip)속에 포함하여 수천 개의 스페로이드를 동시에 배양하 며 약물 또는 다양한 화학물질에 대한 세포반응, 생존성과 해독반응에 대한 연구도 보고되고 있다. ${ }^{38,39)}$ 


\section{연구 동향 및 결론}

보고된 수 많은 연구에서 보여주듯 스페로이드를 포함한 생체모사체에 대한 연구는 생리-의학분야의 주된 연구 모델 이 되어가고 있다. 더불어 공초점 레이져주사현미경(confocal laser scanning microscope), 다양한 조영제를 이용한 마이 크로 자기공명현미경(micro-magnetic resonance microscopy), 양전자방출단층촬영(positron-emission tomography) 및 광학단층촬영기법(optical sectioning technology)을 이 용한 스페로이드 내부의 대사(metabolism), 세포의 생존과 괴사(apoptosis)와 같은 생리작용을 시각화하여 측정할 수 있는 영상기법들 또한 빠르게 발전하고 있다. ${ }^{40-42)}$ 이러한 기 법들이 스페로이드의 기능을 효율적으로 향상시키는 다양한 기법들과 결합되어 조직의 생성, 변화과정과 나아가 유전자 발현을 실시간으로 시각화할 수 있는 연구로 발전해 나갈 것 이며 궁극적으로는 인공장기 또는 임상적으로 적용가능한 이식체 개발에 중요한 역할을 할 것으로 예상된다.

\section{Acknowledgments}

None.

\section{ORCID}

Jae Hong Park

https://orcid.org/0000-0002-5409-5581

\section{REFERENCES}

1) Fatehullah $\mathrm{A}$, Tan $\mathrm{SH}$, Barker N. Organoids as an in vitro model of human development and disease. Nat Cell Biol 2016;18(3):246-54.

2) Cui $X$, Hartanto $Y$, Zhang H. Advances in multicellular spheroids formation. J R Soc Interface 2017;14(127):20160877.

3) Lin RZ, Chou LF, Chien CC, Chang HY. Dynamic analysis of hepatoma spheroid formation: Roles of E-cadherin and beta1integrin. Cell Tissue Res 2006;324(3):411-22.

4) Narayanan RA, Rink A, Beattie CW, Hu WS. Differential gene expression analysis during porcine hepatocyte spheroid formation. Mamm Genome 2002;13(9):515-23.

5) De Witt Hamer PC, Van Tilborg AA, Eijk PP, Sminia P, Troost D, Van Noorden CJF, et al. The genomic profile of human malignant glioma is altered early in primary cell culture and preserved in spheroids. Oncogene 2008;27(14):2091-6.

6) Kunz-Schughart LA, Freyer JP, Hofstaedter F, Ebner R. The use of 3-D cultures for high-throughput screening: The multicellular spheroid model. J Biomol Screen 2004;9(4):273-85.

7) Weaver VM, Lelièvre S, Lakins JN, Chrenek MA, Jones JCR, Giancotti F, et al. beta4 integrin-dependent formation of polarized three-dimensional architecture confers resistance to apoptosis in normal and malignant mammary epithelium. Cancer Cell 2002; 2(3):205-16.

8) Debnath J, Mills KR, Collins NL, Reginato MJ, Muthuswamy SK, Brugge JS. The role of apoptosis in creating and maintaining luminal space within normal and oncogene-expressing mammary acini. Cell 2002;111(1):29-40.

9) Korff T, Kimmina S, Martiny-Baron G, Augustin HG. Blood vessel maturation in a 3-dimensional spheroidal coculture model: Direct contact with smooth muscle cells regulates endothelial cell quiescence and abrogates VEGF responsiveness. FASEB J 2001;15(2):447-57.

10) Kelm JM, Ehler E, Nielsen LK, Schlatter S, Perriard JC, Fussenegger M. Design of artificial myocardial microtissues. Tissue Eng 2004; 10(1-2):201-14.

11) Mironov V, Boland T, Trusk T, Forgacs G, Markwald RR. Organ printing: Computer-aided jet-based 3D tissue engineering. Trends Biotechnol 2003;21(4):157-61.

12) Kelm JM, Timmins NE, Brown CJ, Fussenegger M, Nielsen LK. Method for generation of homogeneous multicellular tumor spheroids applicable to a wide variety of cell types. Biotechnol Bioeng 2003; 83(2):173-80

13) Kelm JM, Fussenegger M. Microscale tissue engineering using gravity-enforced cell assembly. Trends Biotechnol 2004;22(4):195202.

14) de Ridder L, Cornelissen M, de Ridder D. Autologous spheroid culture: A screening tool for human brain tumour invasion. Crit Rev Oncol Hematol 2000;36(2-3):107-22.

15) Wartenberg M, Dönmez F, Ling FC, Acker H, Hescheler J, Sauer H. Tumor-induced angiogenesis studied in confrontation cultures of multicellular tumor spheroids and embryoid bodies grown from pluripotent embryonic stem cells. FASEB J 2001;15(6):995-1005.

16) Yuhas JM, Li AP, Martinez AO, Ladman AJ. A simplified method for production and growth of multicellular tumor spheroids. Cancer Res 1977;37(10):3639-43.

17) Hamilton GA, Westmorel C, George AE. Effects of medium composition on the morphology and function of rat hepatocytes cultured as spheroids and monolayers. In Vitro Cell Dev Biol Anim 2001;37(10):656-67.

18) Wu LY, Di Carlo D, Lee LP. Microfluidic self-assembly of tumor spheroids for anticancer drug discovery. Biomed Microdevices 2008;10(2):197-202.

19) Napolitano AP, Chai P, Dean DM, Morgan JR. Dynamics of the self-assembly of complex cellular aggregates on micromolded nonadhesive hydrogels. Tissue Eng 2007;13(8):2087-94.

20) Dean DM, Napolitano AP, Youssef J, Morgan JR. Rods, tori, and honeycombs: The directed self-assembly of microtissues with prescribed microscale geometries. FASEB J 2007;21(14):4005-12.

21) Karp JM, Yeh J, Eng G, Fukuda J, Blumling J, Suh KY, et al. Controlling size, shape and homogeneity of embryoid bodies using poly(ethylene glycol) microwells. Lab Chip 2007;7(6):786-94.

22) Khademhosseini A, Eng G, Yeh J, Fukuda J, Blumling J 3rd, Langer R, et al. Micromolding of photocrosslinkable hyaluronic acid for cell encapsulation and entrapment. J Biomed Mater Res A 2006;79(3):522-32.

23) Fukuda J, Khademhosseini A, Yeo Y, Yang X, Yeh J, Eng G, et al. Micromolding of photocrosslinkable chitosan hydrogel for spheroid microarray and co-cultures. Biomaterials 2006;27(30):5259-67.

24) Nyberg SL, Hardin J, Amiot B, Argikar UA, Remmel RP, Rinaldo P. Rapid, large-scale formation of porcine hepatocyte spheroids in a novel spheroid reservoir bioartificial liver. Liver Transpl 2005; 11(8):901-10.

25) Song H, David O, Clejan S, Giordano CL, Pappas-Lebeau H, Xu L, et al. Spatial composition of prostate cancer spheroids in mixed and static cultures. Tissue Eng 2004;10(7-8):1266-76.

26) Ingram M, Techy GB, Saroufeem R, Yazan O, Narayan KS, Goodwin $\mathrm{TJ}$, et al. Three-dimensional growth patterns of various human tumor cell lines in simulated microgravity of a NASA bioreactor. In Vitro Cell Dev Biol Anim 1997;33(6):459-66.

27) Unsworth BR, Lelkes PI. Growing tissues in microgravity. Nat Med 1998;4(8):901-7.

28) Du Y, Han R, Ng S, Ni J, Sun W, Wohland T, et al. Identification and characterization of a novel prespheroid 3-dimensional hepatocyte monolayer on galactosylated substratum. Tissue Eng 2007;13(7): 1455-68. 
29) Lu HF, Lim WS, Wang J, Tang ZQ, Zhang PC, Leong KW, et al. Galactosylated PVDF membrane promotes hepatocyte attachment and functional maintenance. Biomaterials 2003;24(27):4893-903.

30) Takezawa T, Mori Y, Yoshizato K. Cell culture on a thermoresponsive polymer surface. Biotechnology (NY) 1990;8(9):854-6.

31) Takezawa T, Mori Y, Yonaha T, Yoshizato K. Characterization of morphology and cellular metabolism during the spheroid formation by fibroblasts. Exp Cell Res 1993;208(2):430-41.

32) Ueno K, Miyashita A, Endoh E, Takezawa T, Yamazaki M, Mori Y, et al. Formation of multicellular spheroids composed of rat hepatocytes. Res Commun Chem Pathol Pharmacol 1992;77(1): 107-20.

33) Elkayam T, Amitay-Shaprut $S$, Dvir-Ginzberg M, Harel T, Cohen $\mathrm{S}$. Enhancing the drug metabolism activities of C3A--a human hepatocyte cell line--by tissue engineering within alginate scaffolds. Tissue Eng 2006;12(5):1357-68.

34) Lin KH, Maeda S, Saito T. Long-term maintenance of liver-specific functions in three-dimensional culture of adult rat hepatocytes with a porous gelatin sponge support. Biotechnol Appl Biochem 1995;21(1):19-27.

35) Akiyama M, Nonomura H, Kamil SH, Ignotz RA. Periosteal cell pellet culture system: A new technique for bone engineering. Cell Transplant 2006;15(6):521-32.
36) Sebastian A, Buckle AM, Markx GH. Tissue engineering with electric fields: Immobilization of mammalian cells in multilayer aggregates using dielectrophoresis. Biotechnol Bioeng 2007;98(3): 694-700.

37) Ino $\mathrm{K}$, Ito $\mathrm{A}$, Honda $\mathrm{H}$. Cell patterning using magnetite nanoparticles and magnetic force. Biotechnol Bioeng 2007;97(5):1309-17.

38) Torisawa YS, Takagi A, Nashimoto Y, Yasukawa T, Shiku H, Matsue T. A multicellular spheroid array to realize spheroid formation, culture, and viability assay on a chip. Biomaterials 2007;28(3):55966.

39) Mohr JC, de Pablo JJ, Palecek SP. 3-D microwell culture of human embryonic stem cells. Biomaterials 2006;27(36):6032-42.

40) Louie AY, Hüber MM, Ahrens ET, Rothbächer U, Moats R, Jacobs $\mathrm{RE}$, et al. In vivo visualization of gene expression using magnetic resonance imaging. Nat Biotechnol 2000;18(3):321-25.

41) Santini MT, Romano R, Rainaldi G, Indovina P, Ferrante A, Motta A, et al. Temporal dynamics of $1 \mathrm{H}-\mathrm{NMR}$-visible metabolites during radiation-induced apoptosis in MG-63 human osteosarcoma spheroids. Radiat Res 2006;166(5):734-45.

42) Huang S, Vader D, Wang Z, Stemmer-Rachamimov A, Weitz DA, Dai $\mathrm{G}$, et al. Using magnetic resonance microscopy to study the growth dynamics of a glioma spheroid in collagen I: A case study. BMC Med Imaging 2008;8:3.

\section{정답 및 해설}

1. 답 (3)

해 설 월경 전 기간에는 성대 점막 부종, 미세혈과 손상 가능성이 증가하므로 수술을 피하는 것이 좋다. 음성 안정이 가능한 시기를 환자와 충분히 상의해서 수술 날짜를 결정(일주일간 절대음성안정, 일주일 후부터 일상적인 대화, 노래는 최소 30 일 이후에) 한다. 특히 전문적 음성 사용자(성악가, 가수, 선생님)는 개인별 일정 고려하여 수술시기를 결정한다. 허밍, 속삭임, 목청소 등은 성대에 좋지 않은 영향을 미친다. 목청소를 하게 되면 오히려 점막 손상이 가중된다. 따라서 이런 경우에는 ‘silent cough'를 권유한다. Silent cough를 하는 방법은 크게 숨을 들이쉰 후 빠르고 강하게 숨을 내쉬는데 이 때 아무런 소리가 나지 않게 한다. 이후 곧바로 턱을 안쪽으로 당긴 후 강하게 침을 삼킨다. 수술 후에도 1 2\% 환자는 별 차도가 없으며 음성의 상태가 나빠질 수 있다. 완전음성휴식(total voice rest) 일반적 7일, 가벼운 발성 7 10일간 유 지하고, 노래 부르기는 3 4주부터 하는 것이 좋다.

참고 문헌: 대한후두음성언어의학회. 후두음성언어의학. 2판. 서울: 범문에듀케이션;2016. p.405-17.

2. 답 (3)

해 설 수술 중 안면신경의 신경모니터링이 필요하기 때문에 수술 중에는 근육이완제의 사용을 피해야 하며, 수술 포를 덮을 때 수술 부위 쪽의 안면을 전부 노출시킨다. 변형 blair 절개, 얼굴성형절개, 이개후두발선절개, 이개주위절개가 있으며 악성인 경우에 림프절 절제술을 하기 위해서는 변형 blair 절개를 주로 한다. 안면신경 줄기를 찾기 위해 이용하는 해부학적 지 표로는 이주연골지표, 고실유동봉합, 후이복근의 근육 부착부위, 신경분지 말단으로부터의 역행성 박리, 유양동 내의 신 경 등이 있다. Frey 증후군을 예방하기 위해 천근건막체계, 흉쇄유돌근, 진피 혹은 진피지방, 대퇴근막, 측두두정골근막 등을 사용하여 기계적인 장벽을 형성할 수 있으며 천근건막체계나 흉쇄유돌근을 가장 많이 사용한다. 수술 후 병리 소견 에서 진행된 병기, 절제연 미확보, 고악성도 종양, 신경 침범, 림프관/혈관 침범이 있으면 방사선 치료의 적응증이 된다. 참고 문헌: 대한이비인후과학회. 이비인후과학:이과. 파주: 군자출판사;2018. p.373-7. 